\title{
Waving at Soldiers
}

\section{Heather Richardson}

\begin{abstract}
I grew up in a middle-class suburb of Belfast during 1960s and 70s, but for most of my writing life I have deliberately avoided writing about the Northern Irish 'Troubles'. Like many of my contemporaries I preferred to leave the place behind, physically and creatively. However, in spite of my determination, the Troubles kept seeping into my creative work - disguised, it's true - but there nevertheless. My fiction is full of war, trauma, and attempts to make a sense of a disrupted world. Over the last few years I've begun to recognise, and accept, that my experience of growing up in Northern Ireland is part of the DNA of my creative work. The piece that follows is the result of my first efforts to capture a sense of that time, and its continuing reverberations.
\end{abstract}

\section{FAMILY NOTICES \#1}

Late August 2014. In the newspaper library just off Royal Avenue, scrolling through microfilms of the Belfast Newsletter for August 1980, almost thirty-four years to the day. Working my way through to the end of the month is a melancholy business, wondering which day's headlines were the last ones he read. Holiday halt in Ulster road deaths proclaims one headline on Monday $25^{\text {th }}$. The slaughter on Ulster's roads took a holiday during the first two days of the annual August break...

\section{TULLYGLASS HOUSE HOTEL}

27 August 1980. It's after midnight. There's a tussle going on in the hotel car park. It's lit up with the overspill from the function suite windows and the headlights of cars edging past the tangle of arguing men.

At the heart of the crowd are my uncles, and at the centre of them all is Uncle Ginge. He's drunk. Not fall-down drunk, but staggering drunk. In one hand he has his car keys. The other uncles try to grab him but he 
outfoxes them every time, dancing away, whipping the keys just out of their grasp. Ginge is ex-army, now a constable in the Royal Ulster Constabulary. If he gets stopped by the police on the way home he'll just flash his warrant card and be on his way. It's understood. So far this year sixtyone people have been murdered, which makes it one of the better years, but still, if a man needs a drink once in a while who can blame him?

We're already in our car, ready to head home. Mum is going to drive, as she always does on the return leg of a night out, with Dad in the passenger seat. Granda is in the back with me on one side of him and Ginge's wife, Auntie Moyra, on the other. Her sisters have conspired to peel her away from her husband tonight. You're not getting in the car with him in that state. We'll drop her off at her house.

Our family is not one for scuffles in hotel car parks. We're hard working, home loving, church going, and while we aren't exactly teetotal I've never seen anyone drunk. Ginge has changed all that, and with his English arrogance he's undaunted by the judgmental gaze of his mother-inlaw - my grandmother - and her other daughters.

Two of the uncles have got hold of Ginge, each of them clinging onto an arm, pulling him this way and that as if it's a tug-of-war and he's the rope. He strains to get away from them, his long legs splayed out to keep his balance. Mum starts the engine.

I feel sorry for Granda. The reason we were all gathered at Tullyglass was for a meal with Canadian relatives. They're travelling back to Toronto tomorrow. One of them is my Granda's brother, and with Granda being seventy-five and his brother even older it isn't likely they'll see each other again. I'm not sure how to console Granda. Our family don't go in for handholding, hugging, saying kind words. As the car drives along the dark County Antrim roads I pretend to go to sleep and let my head droop gradually onto his shoulder. The physical contact, I hope, will comfort him. It isn't much, but it's the best I can do.

I've spent the evening hanging about with my cousin, Rosemary. We flit from table to table, avoiding our parents, ignoring the country relatives men in brown suits, women in polyester frocks - pretending our Woodpecker cider is fizzy apple juice. We sit with Auntie Moyra for a while. She was pretty once, but these days she looks wrung out, dressed in beige, wearing glasses she doesn't really need. She and my mum are the only two people I knew who have genuinely black hair, but Moyra's seems faded now. Not going grey - she's too young for that - but dull, like a tee-shirt that's been washed too many times. Moyra can be hard to talk to. Prickly. She'll snap banalities into tiny pieces, as if she's too clever to abide by the rules of conversation. 
I want more Woodpecker. I dodge past the men who stand between the bar and me, convinced - as tipsy girls often are - that they won't notice me. But here's Ginge, hanging on to a whiskey tumbler as if it's holding him up. 'Been into Belfast lately, Heather?' he says.

'Me? No.' Lying comes naturally to me now. Like a reflex.

'Saturday night?'

I shake my head and push on through to the bar. Saturday night in Belfast? Every Saturday night I can get away with. I'm thorough. Check in the paper to see what film is on at the New Vic and tell Mum and Dad that's where I'm going. Meet up with my friends in front of the city hall, walk through the security gates into Donegal Place and on to Waring Street. Go halfers with Debbie or Midge on a quarter bottle of vodka and two cans of coke from the wee off licence on the corner of Hill Street, and once it's drunk we go into the Harp Bar. Now and again the doorman will decide - for no good reason - to refuse entry to the most blatantly underage. For no good reason because the police never go near the place. One night the army came in, holding their guns in the safeguard position. I don't know what they were looking for. They looked around for five minutes and left. The closest the police ever come is in a meat-wagon parked up on the High Street. The back doors are always closed. I suppose Ginge might have been inside, watching through the window grilles as I walk past.

\section{SOLDIERS \# 1}

The British Army arrived in Northern Ireland in August 1969. I was five years old, so I can't remember a time before they came. There wasn't much sign of them in our suburb of Belfast - a bright network of 1950s houses laid out in ascending lines up a steep slope of the Castlereagh hills - but we'd sometimes be stopped by their roadblocks on trips to visit my dad's country relatives in County Derry. I liked the roadblocks. A soldier would speak in to the car, asking Dad questions in an exotically English accent. They had guns slung around their necks, which I found thrilling. Some of the soldiers were black. I'd never seen black people before, except in photographs of missionary work in Africa.

When I was eight we moved out of our semi to a bigger, newly built house. We didn't go far - down the hill about a quarter of a mile - and the new house had a clear view across Belfast. From my bedroom I could see the mountains on the other side of the city - Divis, Black Mountain, Cave Hill - and the sprawl of buildings that filled the low-lying plain below. I could make out the bright green copper dome of the city hall, the bulk 
of the gasometer at the bottom of the Ormeau Road, and - my particular favourite - the two enormous yellow cranes of the Harland and Woolf shipyard. After dark I liked to watch the red lights on top of the cranes blink on and off. The house sat on an incline above the Knock dual carriageway and I could see the army vehicles speed past, their roar muted by our new-fangled double-glazing. Most often it was a line of landrovers, transporting soldiers to and from the barracks at Holywood, but sometimes the vehicles were more dramatic: Saracen tanks, or - most exciting of all - the windowless moving fortresses known as Flying Pigs, their passing accompanied by the wail of an eerie siren that sounded like something out of a sci-fi film.

In 1975, at eleven years old, I started at my new school. A group of parents organised a driving rota - two dads dropped us off in the morning, and two mums did the afternoon pick-ups. As the car crawled through the morning or afternoon traffic we'd often be stuck behind an army landrover. The back doors would be open, and I'd see two soldiers sitting opposite each other, guns cradled in their laps. I could see movement further back in the interior of the vehicle, a shifting of darkness on darkness - more soldiers. I'd wave at them, and they'd wave back.

As I grew into my teens I took a new interest in the soldiers. I liked the way they wore their trousers tucked into their boots. It was only lately that I'd started noticing what boys wore. I wasn't greatly taken by grammar school boys. They wore Adidas t-shirts and Wrangler jeans and liked boring old-man bands like Genesis. I'd taken to hanging around with punks in Cornmarket on Saturdays. The punk boys wore motorbike jackets, bondage trousers and Doc Marten boots. They were more like the soldiers than they might have liked to think: uniformed, bovver-booted, poker-faced.

\section{WRITING CLASS \#1}

By 2004 I was teaching writing classes all over Belfast. I'd picked up work at an FE college that had little outposts across the city stationed in seventies-shabby buildings. There weren't enough students in any given location to make them viable, but Belfast being Belfast each neighbourhood had to have a campus to itself. Ten years into the peace process and many people still wouldn't venture outside their own area. Even in broad daylight, there were certain roads they wouldn't cross.

My manager spoke to me on the phone ahead of my first class. 'There's a new student in the group,' she said, and told me his name. 'He's very nervous. The others can be a bit full of themselves, so you might need to 
look after him. Make sure he doesn't get overwhelmed.' I guessed this was code. Depression. A breakdown. Something like that.

He was gentle. Softly spoken, so that his Belfast accent was mercifully free of the usual nasal whine. He looked fragile, fine boned, pale-skinned.

I asked the class to write about games they'd played as children. When it came to his turn he read out a piece about a game called Who dies best. 'It was like cowboys and Indians, or Gunfight at the Okay Corral, or cops and robbers,' he explained. 'When you got shot you had to make a meal of it - you know, stretch out the dying for as long as you could. Whoever put on the best performance was the winner.' He paused. 'Funny to think we were out on our street playing at being shot. When you think of what happened after.'

\section{SOLDIERS \#2}

My grandmother kept a photograph of Hitler on the sideboard. That's who I thought he was - the face emerging in smudges of sepia and white from the murk of an old snapshot. 'No, no, that's my father,' she corrected me, 'in his Black Watch uniform.' When I looked closer I saw that what I'd taken to be the sweep of Hitler's dark hair was my great-grandfather's Glengarry bonnet. The bottom half of the photograph was almost totally black, but I could just make out the folds of his kilt. Alexander 'Sandy' Crawford. Irish-born soldier in a Scottish regiment, timing it just right to be too late for the Boer War and too early for the big one. Glasgow tram driver. Presbyterian son-in-law of a Catholic farmer. Labour man. Strong advocate of the education and advancement of women. One woman in particular. His pretty, clever daughter, Agnes. My grandmother.

He had high hopes for her. She qualified as a secretary, and worked in an office in the local market town. She accompanied him to meetings of the Northern Ireland Labour Party. He encouraged her to stand for election, but she demurred. When I asked her why she couldn't remember her reasons. She got engaged to an ambitious young man who set off for Canada to make his fortune. While she waited at home for the summons to the Americas she met another fellow. 'The first time I saw your grandfather,' she said, 'I thought he was the handsomest man I'd ever set eyes on. And I never saw anyone else to make me change my mind.' She visited a fortune teller who said, 'You took off an engagement ring before you came to see me today.' The fiancé in Canada was jilted, and she married my grandfather - a big, quiet, ultra-unionist Orangeman from a backwater village in the middle of a Country Antrim bog. They make a handsome couple in the wedding photograph. Her, in floral 
chiffon and a cloche hat - so different from the roly-poly crimpeleneclad Gran I knew - and, him, with a look of Robert Mitchum about him, dreamy-eyed and pomaded. She gave birth to eight children, and miscarried one or two more that were never spoken of. The baby, Moyra, was born when Gran was forty-three. A wee late one. All my grandmother's energy, passion and ambition was poured into the children. That, and her plan to get herself and her family out of the backwater. 'A miserable hole of a place,' she told me. 'They hated anyone who wanted to better themselves.'

As it happened, it was the children who provided her escape route. One after the other they finished school and found places at university, teacher training college and nursing school in Belfast. Relocation made sense - better than the girls all paying for digs - so they sold the homeplace in the bog and moved to a respectable suburb in East Belfast, close to where C.S. Lewis had grown up. The picture of Gran's uniformed father was packed up and moved to the new house.

It was years later when another soldier appeared in the family. $\mathrm{He}$ was a real flesh and blood one, not a blur in a photograph. A red-haired Englishman, full of swagger and contempt. He was on the arm of Auntie Moyra.

\section{WEDDING}

June 1975. Blistering weather - the sort that made the roads melt and bridesmaids faint. In the days between the $1^{\text {st }}$ and $7^{\text {th }}$ of June, Moyra and Ginge's wedding day, six people had been killed by either the IRA or the British army. By the end of June the death toll reached twenty-three.

Cousin Rosemary and I were bridesmaids, dressed in powder-blue polyester gowns with full-length puffed sleeves and a deep frill at the hem. We'd sweated through the trying-on sessions in the changing room of Dresswell in Newtownards, with our mothers, our grandmother and Auntie Moyra snapping at us and squabbling with each other. I pranced around, swishing the flounces. 'I wish I could dress like this all the time,' I said. Rosemary looked at me scornfully.

The wedding was not in a church or a registry office, but in our house. I don't remember questioning this unorthodox venue, but there were mutterings about security. Ginge was accompanied by two of his soldier friends, and all three were clothed in the mess dress of the $16^{\text {th }} / 5^{\text {th }}$ The Queen's Royal Lancers - short scarlet jackets heavy with braid, close-cut navy trousers with a red stripe down the seam. Their boots were shinier than any I'd seen before, and they wore silver spurs. There was horseplay. His soldier friends man-handled him, tied him to the varnished 


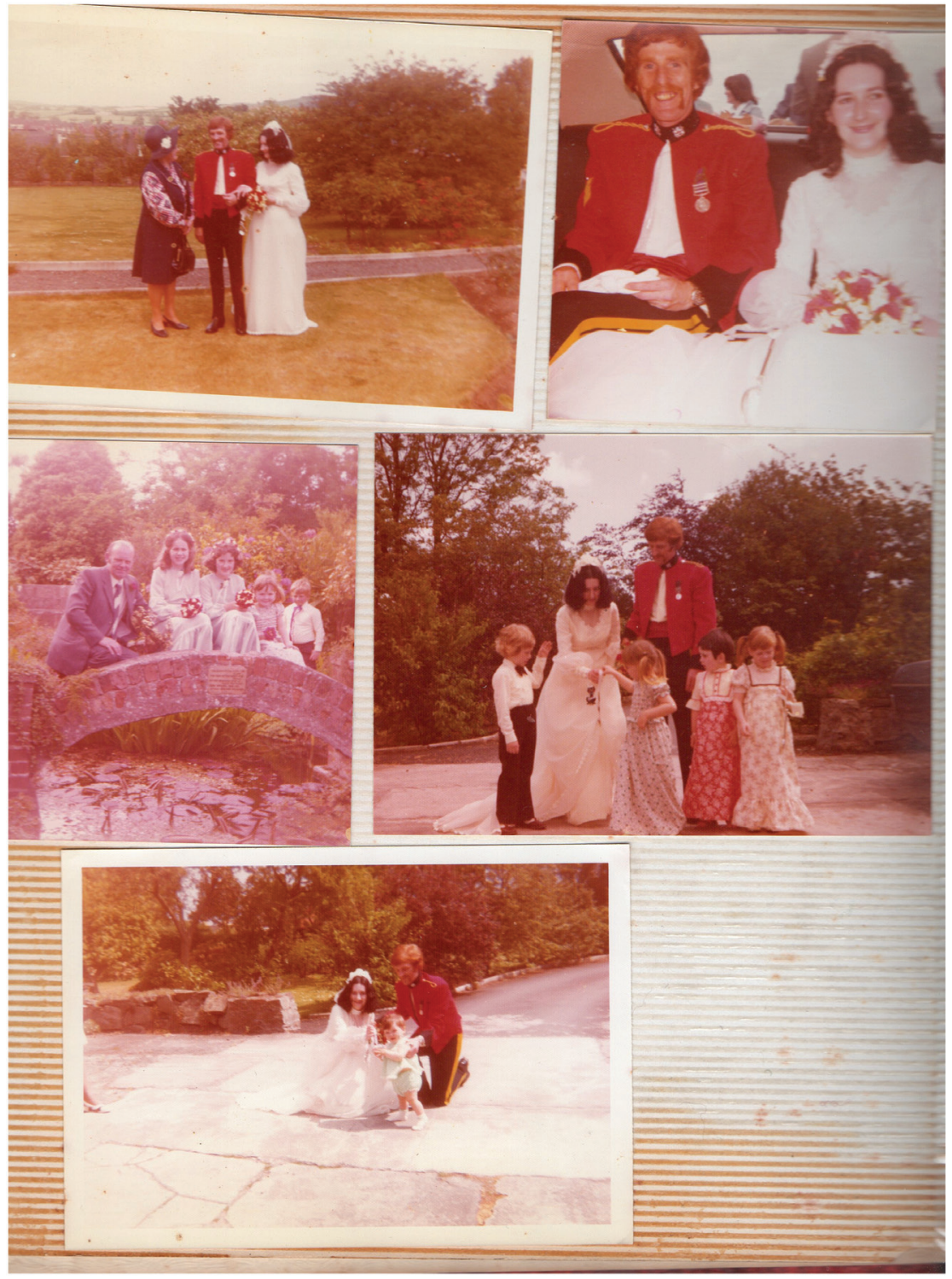

Wedding day snapshots of Auntie Moyra and Ginge, with bridesmaids and flower girls.

mahogany post that supported the veranda, dragged him into the house as he performed the role of reluctant bridegroom. Shiny boots sliding on the red tiles of the porch. The tang of aftershave and whisky, soap 


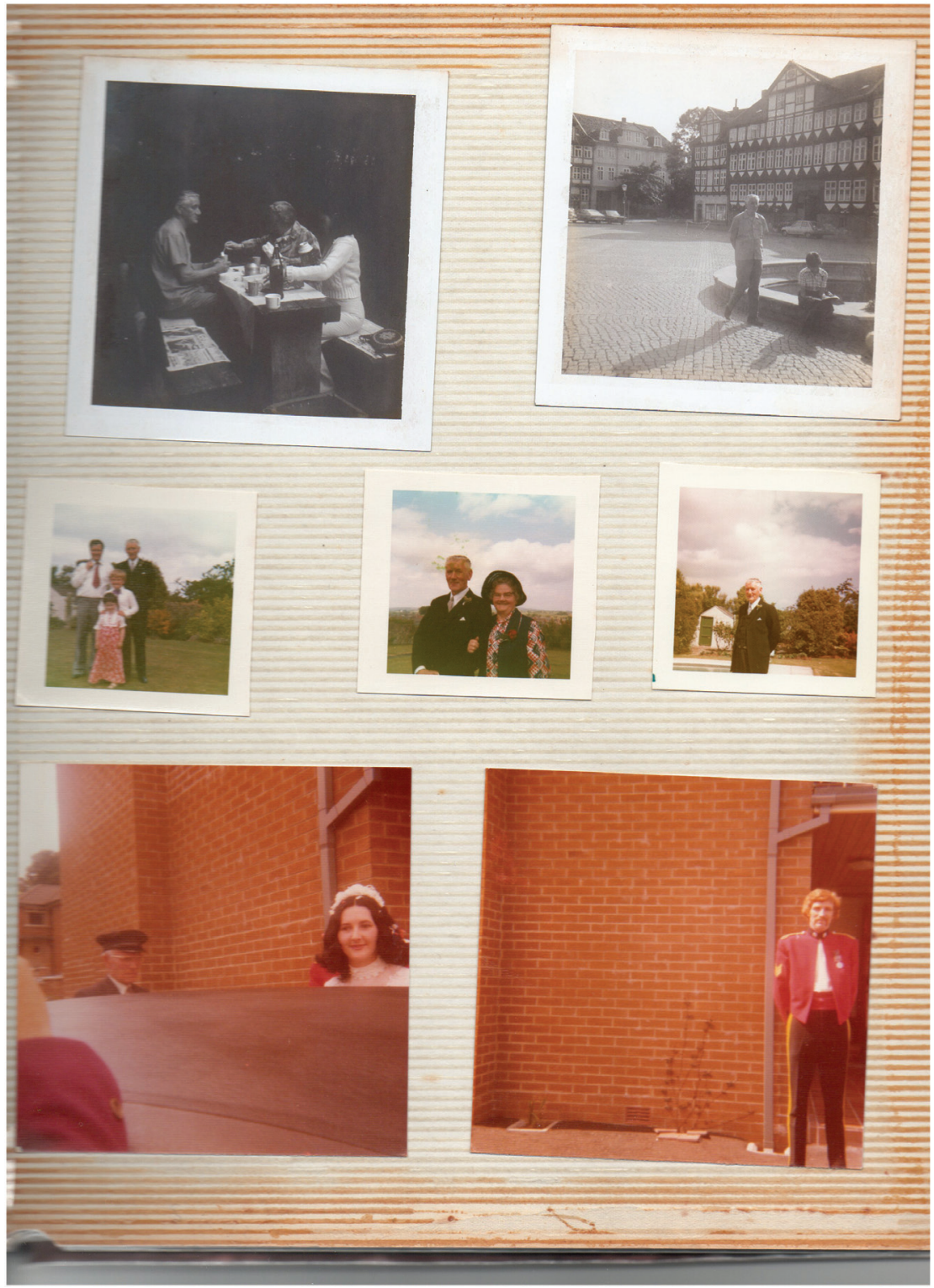

Auntie Moyra and Ginge outside my parents' house after the ceremony. Black \& white photos from Germany, where Ginge was stationed. 
and fresh sweat, muscle and masculinity. Dad looked on unhappily. This was his house - his beautiful new-build - and they acted as if he wasn't there. Not as if they owned the place, but as if the place didn't matter to them at all.

\section{WRITING CLASS \#2}

Claire only ever wrote about her dog. Regardless of the exercise, whatever prompt I gave her, she'd produce a story or poem about her Springer spaniel, praising its many talents. I didn't really mind, although I wished she wouldn't spend so much time showing photos of it to the other students. Everyone knows what a dog looks like.

But one day, for once, she talked about something else. 'There was this young fella in our street. Lovely fella, crippled with shyness. Always walked with his head down, looking at his feet. One day - this was after the British Army came in - there was a soldier standing on the corner of the street. And the young fella came walking, head down as usual, and the soldier just swung his leg up and kicked him, right in the face.' She stopped, looked at me with nervous calculation. The class was on the Falls Road, where everyone had a bad story to tell about the British Army, and everyone was a local except me, with my Scottish first name and English surname and strange hybrid accent from a decade spent living over the water. 'There was no need for it,' she said, as if she thought I might need convincing. 'No need at all.'

\section{AFTERWARDS}

$28^{\text {th }}$ August 1980. I wake late, my head buzzing with a mild hangover. I lie for a while, fantasising about a boy I've convinced myself I fancy because my friend Karen Ann says he's cool. Eventually I get up. The congratulations cards for my O-Levels are still on display on the dressing table, even though the grades weren't much to get excited about. I pull on my dressing gown. It's embarrassingly old - quilted sprigged nylon, crackling with hot static.

Downstairs in the kitchen Mum and Dad are sitting at the table. They look up at me. 'There's been an accident,' Dad says. 'Ginge is dead.'

Mum says, 'We're going to tell people the reason Moyra wasn't in the car with him was because he'd borrowed a video camera from the police, and he had to leave it back.'

Later my big brother sees me crying. 'I didn't think you liked him much,' he says. 
I'm too afraid to go the funeral. I've never been to one. Ginge is being cremated, and I can't face the thought of watching the coffin slide through a curtain into the flames. Cousin Rosemary goes. She wears a patterned blouse. Afterwards, she tells me that one of the uncles said to her, 'You look like you're going to a disco.'

Mum says I can stay at home and help get things ready for after the funeral. Some of the country cousins - Great Aunt Betty and her connection - are boycotting the ceremony, as their church doesn't approve of the unchristian practice of cremation. The women make themselves useful in the kitchen, cutting sandwiches and organising the good china. The men sit in the lounge, smug in fawn suits, and eat. Plates balanced on short, thick legs. Red country faces. Cheeks bulging with sandwiches.

Afterwards Mum and Dad tell me I've been a great help. They've never said anything like that before. At first I can't put my finger on the feeling it gives me, and then I can. They approve of me. For once they approve of me.

There's insurance money, which Moyra will not use for anything sensible. She buys her mother a Canadian squirrel jacket from Jaffa Furs in Fountain Street for £805, and gives the rest to animal charities.

\section{WRITING CLASS \#3}

The women at the trauma centre in North Belfast didn't really want to do creative writing, but they'd go to anything - any activity - to fill the day, to give it shape. They all brought knitting with them, click-clicking baby blankets and matinee jackets into existence - whole wardrobes of white woollen garments generated by their nervous energy.

I drank the tea they made me, and asked them to remember a favourite place from their childhood, the sounds and smells and tastes of it. They talked the stories that they couldn't write down, their grandmothers' houses, bread simmered in milk on the stove to make bowls of belly-filling panada. They talked of wicked aunties who'd taught them to smoke, and the sneaky passing of cigs under the kitchen table.

'I never could smoke in front of my daddy,' one of them said, working the lacy frill on a pram blanket. 'The only time I nearly did it was the night my husband was murdered.' Clickity-click, Clickity-click. 'Daddy was driving me to the hospital and before I knew it I'd the fag out of the packet and in my mouth. Then I realised he was there, so I threw it out the window.' The other women nodded and knitted. You couldn't smoke in front of your father, no matter what the circumstances. 


\section{THE WIDOWS' GARAVAN}

For three summers after Ginge's death Moyra got a free holiday in a caravan on the North Antrim coast, care of the RUC. It was their way of making sure the widows and children of murdered officers had a summer break, for a few years at least. But Moyra and Ginge had no children - he had refused to have any - so instead a stream of aunties, sisters, cousins and nieces visited the caravan. Rosemary and I stayed for days at a time, reading unsuitable books in the dunes and taking the bus into Portrush in the hope of adventures that never materialised. One day Great Aunt Betty - my grandmother's plain-faced sister, widowed early and in triumphant poor health - arrived with a tin of traybakes. 'I'll want that tin back,' she said. 'It's a good tin.'

\section{WRITING CLASS \#4}

The Falls Road class was eclectic. From a teen-mum on benefits to a gentlemanly ancient who favoured the Tridentine Mass and always wore a collar and tie. The old ones wrote about their past. The young ones imagined dramas in sinister country mansions.

One elderly lady quaked with unquenched rage as she read her piece on the remembered cruelty of a nun to her eight-year-old self, decades earlier. Another told us how, in the 1950s with no money for starch, she'd washed her net petticoats in sugar water and hung them to stiffen on the clothesline. One summer evening she was late for a dance, and ran for the bus pursued by wasps, sugar water dripping down her legs.

A retired schoolteacher talked about the day her brother was murdered. 'Someone at the hospital told me how many people had been killed in the troubles - told me what number my brother was. By the time I left it was nearly daybreak. A beautiful day. The sky was lightening. It had never really hit me before, just how many people had died. But that morning, it was as if all those other deaths were pressing down on me. And it wasn't just my brother's death I was feeling. It was all of them.'

\section{FAMILY NOTICES \#2}

Ginge was pronounced dead at the Waveney Hospital, Ballymena on $27^{\text {th }}$ August 1980. The cause of death was laceration of the brain associated with multiple skull fractures. 
There were only four death notices placed in the newspaper. From his wife, her parents, the Police Federation of Northern Ireland, and one from his unnamed colleagues in the Tactical Support Unit.

My dad identified the body. After the funeral he was tasked with collecting the ashes. He said they didn't amount to much. A handful or two of gritty dust. He said that in spite of all that he still had a feeling that Ginge had pulled a fast one. Had somehow got away. Had perhaps stepped out of his life and moved on to something new.

When I try to talk to Dad about Ginge now he clams up. It makes him uncomfortable.

My husband wonders what I'm trying to find out. I say I don't know, but I think it's something to do with stories. We're going to tell people... my mum said, after he died, as if what we tell people is the most important thing of all.

\section{BIOGRAPHICAL NOTE}

Heather Richardson's first novel, Magdeburg, was published by Lagan Press in 2010, and a short story mini-collection, Chilled, appeared as a Kindle ebook in 2011. She is a former winner of the Brian Moore Short Story Award, and her short fiction has been published in magazines and anthologies in the UK and Ireland. In 2014 she completed a PhD in Creative Writing with the Open University, where she is now a Lecturer in Creative Writing. 